\title{
Clinical study of anemia in women attending the College of Medical Sciences Bharatpur
}

\section{Pradhan M}

Department of General Practice and Emergency Medicine,College of Medical Sciences, Bharatpur, Nepal

\begin{abstract}
OBJECTIVE

To study the clinical profile of Anemia in Women attending the College of Medical Sciences-Teaching Hospital, Bharatpur, Chitwan.

\section{MATERIALS \& METHODS}

The Study was conducted among 100 women patients attended to the College of Medical SciencesTeaching Hospital, Bharatpur, Chitwan. Their blood samples were tested and related socio-demographic information was collected. The associated Clinical signs and symptoms with hemoglobin level and the occurrence of anemia were assessed.
\end{abstract}

\section{RESULT}

The peak incidence of Anemia was in the age group of 20-24 yrs (59.7\%), and severity of anemia was correlated with sings and symptoms. Majority of them had Microcytic Hypochromic anemia (43.1\%) with serum iron level below normal level and increased TIBC (total iron binding capacity) were observed.

\section{CONCLUSION}

The high prevalence of Nutritional anemia suggests the dietary advice to be emphasized strongly.

\section{Key Words: Anemia, Haemoglobin, Deficiency of Iron and Serum $\mathrm{B}_{12}$}

\section{INTRODUCTION}

Anemia is a global health problem affecting both developing and developed countries, with major problem for human health as well as social and economic development. It occurs at all ages of life, depending on the cause. At the beginning of the $19^{\text {th }}$ century the word anemia was a clinical term referring Correspondence: Dr. Manohar Pradhan E-mail:manoharpradhan@hotmail.com to pallor of skin and mucus membrane. Prevalence in non-industrialized countries varies between $35 \%$ to $60 \%$ with average being $56 \%$. $^{1}$ The prevalence is very high in the central Asia reported being 70\% in India. ${ }^{2}$ Commonly it is due to iron deficiency because high iron requirements which is not fulfilled by dietary intake.

Ignorance, poverty and gender bias significantly contributes to this high prevalence. ${ }^{3-6}$ Even as mankind marches into the new millennium the disease still 
Journal of College of Medical Sciences-Nepal, 2014, Vol-10, No-3

remains incomplete. Nepal with its population of 22 million is one of the poorest countries in the world and maternal deaths due to anemia are considered the predominant cause of death. Recent WHO data shows that 10.8 million in African countries, 9.7 million in western pacific and 24.8 million is South East Asia or Anaemic, the highest being in South East Asia. ${ }^{7}$

Nutritional anemia is one of the main health problems in developing countries. Unfortunately only few accurate statistics of the prevalence and even less information is available on iron, Vitamin $\mathrm{B}_{12}$ \& Folic Acid. A study by Thangleela T and Vijaylaxmi $\mathrm{P}^{8}$ stated parity of woman had significant influence on her $\mathrm{Hb}$. status. The mean $\mathrm{Hb}$ level of multigravida was much lower than primary, secondary and third gravida.

The study by Drey M et al Nepal ${ }^{9}$. Mehrotra M et al India $^{10}$ Batool. Z. Zafar Pakistan ${ }^{11}$, Sreegiri S et al India ${ }^{12}$ had shown the degree of anemia among women greatly depend on the economic status and the literacy rate. Nutritional anemia is one of the main health problems in many countries but unfortunately there are only few statistics of the prevalence of various types of anemia. Other cause of anemia, include parasitic infestation, ${ }^{13}$ infections like Malaria, TB, HIV and also other micro nutrient deficiencies.

WHO defines anemia as hemoglobin concentration of less than $11 \mathrm{gm} / \mathrm{dl}$ and haematocrit of less than $0.33^{1}$. A typical iron deficiency anemia shows $\mathrm{Hb}$ less than $10 \mathrm{gm} \%$, RBC less than 4 million per $\mathrm{mm}^{3}$, PCV less than $30 \% \mathrm{MCHC}$ less than $30 \%$, MCV less than 75/ $\mathrm{mm}^{3}, \mathrm{MCH}$ less than $25 \mathrm{pgm}$.

Nepal being a poor country, contributes a huge percentage of global burden. Unfortunately there are notmuch of literatures available on the studies conducted in this part of the world. Keeping in view of the early diagnosis and to observe the magnitude and common type of anemia among women in this region this prospective study was under taken at CMS-TH, Bharatpur, Chitwan.

\section{MATERIALS AND METHOD}

A total No of 100 cases were studied for duration of 3 years, from January 2011 to December 2013. A detailed questionnaire regarding in patient number, age, address, occupation, religion, social-economic status, detail history, regarding menstrual cycle, age of menarche, regularity of cycle, age at marriage, parity were considered.

History of general weakness, fatigue, shortness of breath, palpitation, nausea and vomiting, loss of wt., swelling of feet, loss of appetite, headache, paresthesia, glossitis, cheilities. Any medical history of HTN, DM, and venereal disease was taken. Generalized physical examination was carried out with special reference to pallor of skin and mucous membrane, pulse and blood pressure was noted. All cases with Hb less than 11 gm/dl were selected. Blood investigation was carried out for complete hemogram, PBS, serum iron, TIBC, serum Vitamin B12. 


\section{AGE DISTRIBUTION}

Out of 100 patients 72 of them had Hb less than $11 \mathrm{gm} /$ dl Minimum age was 18 yrs and maximum was 32 years Mean age 23 years. It was observed that women belonging to age group 20-24 years had higher frequency than other age group. (table 1)

Table 1: Age distribution

\begin{tabular}{|lcc|}
\hline Age in years & No of cases & Percentage \\
\hline $15-19$ yrs & 12 & $16.7 \%$ \\
$20-24$ yrs & 43 & $59.7 \%$ \\
$25-29$ yrs & 14 & $19.4 \%$ \\
$30-34$ yrs & 13 & $4.2 \%$
\end{tabular}

This study showed the most frequent degree was moderate degree of anemia. (table 2)

Table No 2: Degree of Anemia

$\begin{array}{lcc}\begin{array}{l}\text { Frequency of } \\ \text { degree of anemia }\end{array} & \begin{array}{c}\text { No. of } \\ \text { cases }\end{array} & \text { Percentage } \\ \text { Mild } & 33 & 45.8 \% \\ \text { Moderate } & 37 & 51.4 \% \\ \text { Severe } & 2 & 2.8 \% \\ \text { Total } & \mathbf{7 2} & \mathbf{1 0 0} \%\end{array}$

Most frequent type of anemia found by peripheral blood smear was Microcytic Hypo chromic type of anemia. (table 3)

\section{Table 3: Peripheral Blood Smear}

Type Frequency Percentage

$\begin{array}{lcc}\text { Microcytic/Hypochromic } & 31 & 43 \% \\ \text { Macrocytic/Hyperchromic } & 1 & 1.4 \% \\ \text { Dimorphic } & 7 & 9.4 \% \\ \text { Normocytic/Normochromic } & 24 & 33.3 \% \\ \text { Normocytic/Hypochromic } & 9 & 12.5 \% \\ \text { Total } & \mathbf{7 2} & \mathbf{1 0 0} \%\end{array}$

As represented in table 4, it was observed that out of 72 patients, 25 of them had serum iron level below than normal range and had been observed among patient. With Microcytic/Hypochromic anemia, than others. (Normal serum iron 39-145 microgm/ltr).

Table 4: Relationships between serum iron level \& type of Anemia

$\begin{array}{lccc}\text { PBS } & \begin{array}{c}\text { Below } \\ \text { (N) }\end{array} & \begin{array}{c}\text { Within } \\ \text { (N) }\end{array} & \text { Total } \\ \text { Microcytic/Hypochromic } & 14 & 17 & 31 \\ \text { Macrocytic/Hyperchromic } & 0 & 1 & 1 \\ \text { Dimorphic } & 4 & 3 & 7 \\ \text { Normocytic/Normochromic } & 6 & 18 & 24 \\ \text { Normocytic/Hypochromic } & 1 & 8 & 9 \\ \text { Total } & \mathbf{2 5} & \mathbf{4 7} & \mathbf{7 2} \\ & (\mathbf{3 4 . 7 \% )} & (\mathbf{6 5 . 3 \% )} & \mathbf{( 1 0 0 \% )}\end{array}$

As shown in table 5, 23 patients had serum $B_{12}$ below normal range. Normal serum $B_{12}$ is $240-900$ Micro gm/ltr 
Journal of College of Medical Sciences-Nepal, 2014, Vol-10, No-3

Table 5: Serum $B_{12}$ levels

$\begin{array}{lcc}\text { B }_{\mathbf{1 2}} \text { range } & \text { Frequency } & \text { Percentage } \\ \text { Below normal range } & 23 & 31.9 \% \\ \text { Within normal range } & 49 & 68.1 \% \\ \text { Total } & \mathbf{7 2} & \mathbf{1 0 0} \%\end{array}$

The present study showed that, out of 72 anemic patients, 25 of them had serum iron below normal range. (Table 6)

\section{Table 6: Serum Iron}

\begin{tabular}{lcc|}
$\begin{array}{l}\text { Serum Iron (39-145) } \\
\text { micro gm/lt }\end{array}$ & $\begin{array}{l}\text { No of } \\
\text { Cases }\end{array}$ & Percentage \\
\hline Below lower range & 25 & $34.7 \%$ \\
Within Normal range & 47 & $65.3 \%$ \\
Total & $\mathbf{7 2}$ & $\mathbf{1 0 0 \%}$ \\
\hline
\end{tabular}

Table 7: Relation between Peripheral Blood Smear and TIBC

\begin{tabular}{lccc}
\multicolumn{4}{c}{ TIBC 262-464 Microgram/dl } \\
PBS & Below & Above & Total \\
& Normal & Normal & \\
& & & \\
$\begin{array}{l}\text { Microcytic } \\
\text { Hypochromic }\end{array}$ & 1 & 30 & 31 \\
$\begin{array}{l}\text { Macrocytic/ } \\
\text { Hyperchromic }\end{array}$ & 0 & 1 & 1 \\
$\begin{array}{l}\text { Dimorphic } \\
\text { Normocytic/ } \\
\text { Norchromic }\end{array}$ & 1 & 6 & 7 \\
$\begin{array}{l}\text { Normocytic/ } \\
\text { Hypochromic }\end{array}$ & 0 & 9 & 9 \\
Total & $\mathbf{3}$ & $\mathbf{6 9}$ & $\mathbf{7 2}$ \\
& $\mathbf{( 4 . 2 \% )}$ & $\mathbf{( 9 5 . 8 \% )}$ & $\mathbf{( 1 0 0 \% )}$
\end{tabular}

The present study showed general weakness was the most common presentation among the anemic patients. (table 8)

Table 8: Frequency of different Symptoms

$\begin{array}{lcc}\text { Symptoms } & \text { No of cases } & \text { Percentages } \\ \text { General weakness } & 62 & 86 \% \\ \text { Short ness of Breath } & 49 & 68 \% \\ \text { Nausea \& Vomiting } & 30 & 41.7 \% \\ \text { Palpitation } & 18 & 25 \% \\ \text { Pedal odema } & 15 & 20.8 \% \\ \text { Headach } & 13 & 18.1 \% \\ \text { Paresthesia } & 5 & 6.9 \% \\ \text { Glossitis } & 5 & 6.9 \% \\ \text { Chelitis } & 3 & 4.2 \%\end{array}$

\section{Common Causes of Anemia}

1. Nutritional Deficiency
a. Iron deficiency
$43 \%$
b. Folate and Vit $\mathrm{B}_{12}$
$1.4 \%$
c. Dimorphic
$9.4 \%$

\section{Infections:}
a. Hook worm infestation
$15 \%$
b. Ascariasis
$10 \%$
c. Giardia Lambia
$10 \%$ 

d. Trichuris
e. Malaria
f. HIV Infection
g. Drugs
h. Renal decease
$12 \%$

\section{Normocytic Normochromic}

1. Chronic liver disease.

2. Chronic. Renal disease

$33 \%$

3. Myxedema

$47 \%$

4. Myelodysplastic disorder $\quad 0 \%$

5. Myeloproliferative disorder

$13 \%$

6. Hereditary sideroblastic

\section{DISCUSSION}

Anemia is the most common nutritional problem among women, affecting 230 million women in the developing world was noted. In the present study, out of total 100 cases screened for anemia $72 \%$ were found to have anemia of varying degree using the cut off value of $\mathrm{Hb}<11 \mathrm{gm} / \mathrm{dl} .^{14}$

In the developing countries anemia is probably due to poor Nutrition, worm infestation however lower incidence among western countries can be attributable to the fact that people are placed in better environment their dietary habit and socio economic condition are better.

In the present study, moderate degree of anemia outnumbered both mild $\&$ severe degree of anemia. About $43.1 \%$ had Mic/Hypo anemia 33.3\% showed Normo/Normochromic anemia \& $9.7 \%$ had Dimorphc anemia \& only $1.4 \%$ had macrocytic anemia as evaluated by PBS \& absolute values. According to various studies the most common type of anemia is iron deficiency anemia. These anemias are common is those who have inadequate nutritional diet and receiving iron folate supplement. The result of the present study of serum iron and TIBC in Micro/ Hyporochromic and dimorphic anemia were found to be in close approximation with those of Bondvik $\mathrm{G}$ et a ${ }^{15}$ conducted in Nepal.

This study showed $86 \%$ of the patients presented with generalize weakness $68 \%$ with SOB, $41.7 \%$ with nausea and vomiting, $25 \%$ palpitation, $20.8 \%$ with pedal edema, $18.1 \%$ with headache, $6.9 \%$ with parathesias, $6.9 \%$ with glossitis and $4.2 \%$ with cheilitis. This also revealed to most of the women from rural community were more anemic than from urban area it gives evidence that education and income reduced the symptoms of anemia. This indicates that mother education influences links with better health \& food practices such as proper use of medicine at proper time, proper consultation with health professional's, proper food intake and many more, resulting in direct effect on her health.

\section{CONCLUSION}

Among 100 patients, $72 \mathrm{had} \mathrm{Hb}<11 \mathrm{gm} / \mathrm{dl}$ with mean age of 23 years. It was observed that women belonging to age group 20-24 years had higher frequency than 
Journal of College of Medical Sciences-Nepal, 2014, Vol-10, No-3

other age group. The most frequent $(51.4 \%)$ was observed of moderate anemia. The most frequent anemia found by the peripheral blood smear was Microcytic Hypochromic anemia.

The most common presentation among anemic patients was generalized weakness (86\%) and shortness of breath in $(68 \%)$. The most common cause was found to be iron deficiency anemia. The most common infection was malaria (35\%) and most common cause for normocytic normochromic anemia was myxedema $(47 \%)$.

Low serum B12 level was found in $32 \%$ of woman. In microcytic hyprochromic anemia and dimorphic anemia, mean serum iron was found to be low with a raised total iron binding capacity.

\section{REFERENCES}

1. World Health Organization WHO Global Data base, Geneva 1997.

2. Sarin AR. Severe anemia of pregnangy, recent experience. Int. J Gynecol.obst. 1995;50: 545-5.

3. Letsky EA. The Hematological system in Hytten Fe. Chamberlein GVP, Eds clinical Physiology in obstetrics $2^{\text {nd }}$ Ed.Oxford, UK Blackwall scientific publication 1991, 39-82.V.fredon I Cavill, J.Frisher iron stores in pregnancy. Br J Hematology 1977;37.145-9

4. NIN-annual report of Indian Council of Medical Research. Hyd.India NIN 1972.

5. Sharma JB, Hurthg DNS etal. Effect of dietary habits on prevalence of anemia is pregnant Women of Delhi. $J$ obst-Gynec 2003;29.73-8.
6. Rayston E, the prevalence of nutritional anemia in women in developling countries: a critical review of available information . world Health Statistics Quartely 1982;35(2):52-91.

7. Thangleela J, Vigaylaxmi P. Prevalance of anemia is pregnancy. The Indian Journal of Nutr and Diet 1991;31(2):26-9.

8. Drey Juss HL, Coltz RJ, Shrestha JB, et al. Hook warm, malaria and Vit $\mathrm{B}^{12}$ deficiency contributes to Anemia and iron deficiency among women is the plains of Nepal. JNutr 2000;130:2527-36.

9. Mehrotra M, Tiwari S. A study of dietary pattern of women of Harahua block of Varanarsi, India J Prev Soc Med 2008;39(10):83-5.

10. Batool Z. Zafor M, Maan AA, et al. T Social Factors affecting anemia and their effects on Mother And Child health after delivery in rural areas of dristict Faislabad, Punjab, Pakistan, PakJ Agri Sci 2010;47(1)59-65.

11. Sreegiri S, Babu K, Madhavi BD. Across sectional study of nutritional status of antenatal mothers in rural areas of Vishakapatanam, APJ com Med 2010;6(1)60-40.

12. Nurdiati DS, Sumani S, Hakimi M, et al. Impact of intestinal helminthic infection on anemia and iron status during pregnancy: a community based study in Indonesia. South east Asia J trip Med public health 2001;3214-20.

13. Steketee RK, Nahlen BL, Praise M, et al. The burden of Malaria in pregnancy in Malaria - Endemic areas. Am J Trip Hedhyg 2001;64:28-35.

14. Chumak EL, Girjbouski AM. Anemia in Women international Journal ofCircumpolar Health 2010;69:265-71.

15. Aikawa R, Khan NC, Sasaki S, et al. Risk factors for iron deficiency anemia among women living in rural Vietnam and Turkey. Public health nutrition 2005;9(4):443-8. 